\title{
A Few Covid Vaccine Recipients Developed a Rare Blood Disorder.
}

Davison Grady (1)

\section{ARTIGO ORIGINAL}

Abstract

EMA's safety committee (PRAC) has concluded today that unusual blood clots with low blood platelets should be listed as very rare side effects of Vaxzevria (formerly COVID-19 Vaccine AstraZeneca). In reaching its conclusion, the committee took into consideration all currently available evidence, including the advice from an ad hoc expert group. EMA is reminding healthcare professionals and people receiving the vaccine to remain aware of the possibility of very rare cases of blood clots combined with low levels of blood platelets occurring within 2 weeks of vaccination. So far, most of the cases reported have occurred in women under 60 years of age within 2 weeks of vaccination. Based on the currently available evidence, specific risk factors have not been confirmed.

Keywords: COVID 19, Vaccines, Blood Clots. 


\section{Alguns destinatários de vacinas COVID desenvolveram um distúrbio sanguíneo raro.}

\section{Resumo}

O comitê de segurança da EMA (PRAC) concluiu hoje que coágulos sanguíneos incomuns com baixo teor de plaquetas deve ser listados como efeitos colaterais muito raros de Vaxzevria (anteriormente COVID-19 Vacina AstraZeneca). Para chegar à sua conclusão, o comitê levou em consideração todas as evidências atualmente disponíveis, incluindo o conselho de um grupo de especialistas ad hoc. A EMA está a lembrar os profissionais de saúde e as pessoas a tomar a vacina para se manterem cientes da possibilidade de ocorrerem casos muito raros de coágulos sanguíneos combinados com níveis baixos de plaquetas sanguíneas nas 2 semanas após a vacinação. Até agora, a maioria dos casos relatados ocorreu em mulheres com menos de 60 anos de idade nas 2 semanas seguintes à vacinação. Com base nas evidências atualmente disponíveis, os fatores de risco específicos não foram confirmados.

Palavras-chave: COVID 19, Vacinas, Coágulos sanguíneos.

Instituição afiliada: 1- Junior researcher of the group combat against covid 19 - New York - USA. Dados da publicação: Artigo recebido em 03 de junho, revisado em 25 de junho, aceito para publicação em 10 de Agosto e publicado em 05 de Setembro.

DOI: https://doi.org/10.36557/2674-8169.2021v3n8p07-14

Davison Grady ggradyd@gmail.com

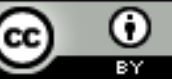

This work is licensed under a Creative Commons Attribution 4.0 International

License. 


\section{INTRODUÇÃO}

EMA's safety committee (PRAC) has concluded today that unusual blood clots with low blood platelets should be listed as very rare side effects of Vaxzevria (formerly COVID19 Vaccine AstraZeneca).

In reaching its conclusion, the committee took into consideration all currently available evidence, including the advice from an ad hoc expert group.

EMA is reminding healthcare professionals and people receiving the vaccine to remain aware of the possibility of very rare cases of blood clots combined with low levels of blood platelets occurring within 2 weeks of vaccination. So far, most of the cases reported have occurred in women under 60 years of age within 2 weeks of vaccination. Based on the currently available evidence, specific risk factors have not been confirmed.

People who have received the vaccine should seek medical assistance immediately if they develop symptoms of this combination of blood clots and low blood platelets (see below).

The PRAC noted that the blood clots occurred in veins in the brain (cerebral venous sinus thrombosis, CVST) and the abdomen (splanchnic vein thrombosis) and in arteries, together with low levels of blood platelets and sometimes bleeding.

The Committee carried out an in-depth review of 62 cases of cerebral venous sinus thrombosis and 24 cases of splanchnic vein thrombosis reported in the EU drug safety database (EudraVigilance) as of 22 March 2021, 18 of which were fatal. ${ }^{1}$ The cases came mainly from spontaneous reporting systems of the EEA and the UK, where around 25 million people had received the vaccine.

COVID-19 is associated with a risk of hospitalisation and death. The reported combination of blood clots and low blood platelets is very rare, and the overall benefits of the vaccine in preventing COVID-19 outweigh the risks of side effects.

EMA's scientific assessment underpins the safe and effective use of COVID-19 vaccines. Use of the vaccine during vaccination campaigns at national level will also take into account the pandemic situation and vaccine availability in the individual Member State.

One plausible explanation for the combination of blood clots and low blood platelets is an immune response, leading to a condition similar to one seen sometimes in patients treated with heparin (heparin induced thrombocytopenia, HIT). The PRAC has requested new studies and amendments to ongoing ones to provide more information and will take any further actions necessary. 
The PRAC stresses the importance of prompt specialist medical treatment. By recognising the signs of bloods clots and low blood platelets and treating them early, healthcare professionals can help those affected in their recovery and avoid complications.

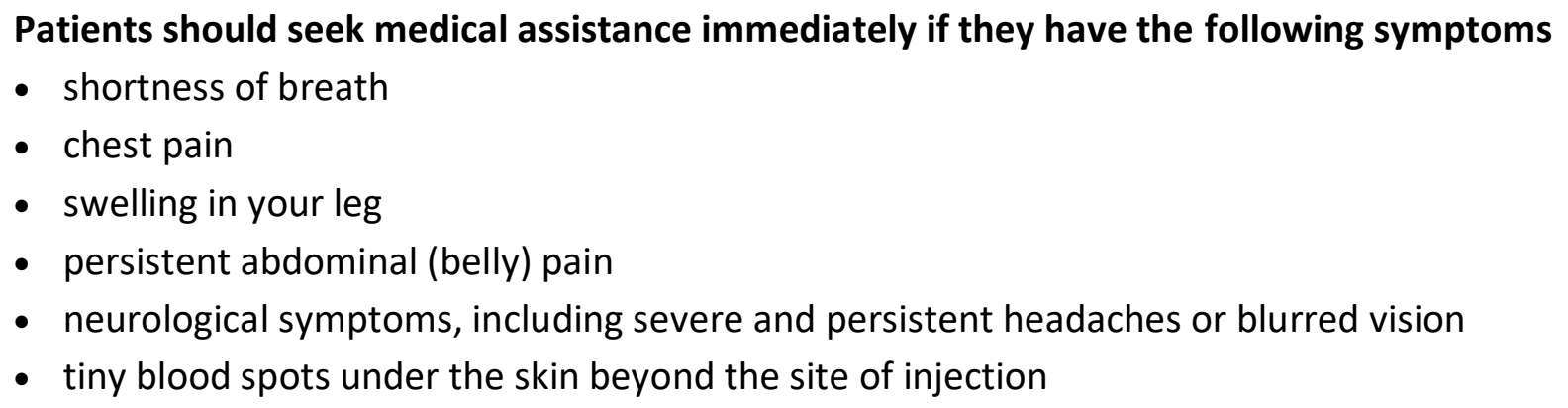

Vaxzevria is one of four vaccines authorised in the EU for protecting against COVID-19. Studies show that it is effective at preventing the disease. It also reduces the risk of hospitalisation and deaths from COVID-19.

As for all vaccines, EMA will continue to monitor the vaccine's safety and effectiveness and provide the public with the latest information.

\section{Information for the general public}

- Cases of unusual blood clots with low platelets have occurred in people who received Vaxzevria (formerly COVID-19 Vaccine AstraZeneca).

- The chance of having this occur is very low, but you should still be aware of symptoms so you can get prompt medical treatment to help recovery and avoid complications.

- You must seek urgent medical attention immediately if you have any of the following symptoms in the weeks after your injection:

- shortness of breath

- chest pain

- leg swelling

- persistent abdominal (belly) pain

- neurological symptoms, such as severe and persistent headaches or blurred

vision

- tiny blood spots under the skin beyond the site of the injection.

- Speak to your healthcare professional or contact your relevant national health authorities if you have any questions about the roll out of the vaccine in your country.

\section{Information for healthcare professionals}


- EMA has reviewed cases of thrombosis in combination with thrombocytopenia, and in some cases bleeding, in people who received Vaxzevria (formerly COVID-19 Vaccine AstraZeneca).

- These very rare types of thrombosis (with thrombocytopenia) included venous thrombosis in unusual sites such as cerebral venous sinus thrombosis and splanchnic vein thrombosis as well as arterial thrombosis. Most of the cases reported so far have occurred in women under the age of 60 years. Most cases occurred within 2 weeks of the person receiving their first dose. There is limited experience with the second dose.

- As for the mechanism, it is thought that the vaccine may trigger an immune response leading to an atypical heparin-induced-thrombocytopenia like disorder. At this time, it is not possible to identify specific risk factors.

- Healthcare professionals should be alert to the signs and symptoms of thromboembolism and thrombocytopenia so that they can promptly treat people affected in line with available guidelines.

- Healthcare professionals should tell people receiving the vaccine that they must seek medical attention if they develop:

- symptoms of blood clots such as shortness of breath, chest pain, leg swelling, persistent abdominal pain

o neurological symptoms such as severe and persistent headaches and blurred vision

- petechiae beyond the site of vaccination after a few days.

- The benefits of the vaccine continue to outweigh the risks for people who receive it. The vaccine is effective at preventing COVID-19 and reducing hospitalisations and deaths.

- National authorities may provide additional guidance on the roll out of the vaccine based on the situation in your country.

Healthcare professionals involved in giving the vaccine in the EU will receive a direct healthcare professional communication (DHPC). The DHPC will also be available.

\section{More about the medicine}

Vaxzevria (formerly COVID-19 Vaccine AstraZeneca) is a vaccine for preventing coronavirus disease 2019 (COVID-19) in people aged 18 years and older. COVID-19 is caused by SARS-CoV-2 virus. COVID-19 Vaccine AstraZeneca is made up of another virus (of the adenovirus family) that has been modified to contain the gene for making a protein from SARSCoV-2. The vaccine does not contain the virus itself and cannot cause COVID-19. 
The most common side effects are usually mild or moderate and improve within a few days after vaccination.

\section{More about the procedure}

This review was carried out in the context of a safety signal, under an accelerated timetable. A safety signal is information on a new or incompletely documented adverse event that is potentially caused by a medicine such as a vaccine and that warrants further investigation.

The review was carried out by EMA's Pharmacovigilance Risk Assessment Committee (PRAC), the Committee responsible for the evaluation of safety issues for human medicines. EMA's human medicine committee, CHMP, will now rapidly assess any necessary changes to the product information.

EMA's scientific assessment underpins the safe and effective use of COVID-19 vaccines. EMA's recommendations are the foundation upon which individual EU Member States will design and implement their own national vaccination campaigns. These may differ from country to country depending on their national needs and circumstances, such as infection rates, priority populations, vaccine availability and hospitalisation rates. $1,2,3,4,5$

\section{THE AUTHORS DECLARE NO CONFLICTS OF INTEREST.}

\section{REFERÊNCIAS}

1- EMA confirms overall benefit-risk remains positive https://www.ema.europa.eu/en/news/astrazenecas-covid-19-vaccine-ema-findspossible-link-very-rare-cases-unusual-blood-clots-low-blood

2- A Small Number of People Developed This Rare Blood Disorder After Getting a COVID Vaccine-Here's What to Know. https://www.health.com/condition/infectiousdiseases/coronavirus/rare-blood-disorder-covid-vaccine-thrombocytopenia

3- Can people with blood infections or disorders get vaccines? https://covidvaccinehub.org/articles/can-people-with-blood-infections-or-disorders-getvaccines

4- Canadian researchers closer to understanding how $A Z$ vaccine recipients develop rare blood clots. https://www.ctvnews.ca/health/coronavirus/canadian-researchers-closerto-understanding-how-az-vaccine-recipients-develop-rare-blood-clots-1.5500015

5- Can the COVID-19 vaccine lead to lethal thrombocytopenia? https://healthdesk.org/articles/can-the-covid-19-vaccine-lead-to-lethal-thrombocytopenia 